\title{
BLACK RUST AND OCCURRENCE OF BERBERIDACEAE IN FINLAND
}

\author{
E. A. Jamalainen \\ Department of Plant Pathology, Agricultural Research Centre, Tikkurila.
}

Received 14th February 1953

Black Rust (Puccinia graminis Pers.), which is a common disease of cereals in Finland, is not known to have caused so great damage before as to in spring wheat in 1951. In the same year black rust caused great damage also in other Northern Countries, in Sweden (8) and in Denmark $(1,6)$.

\section{Spread of black rust and damage caused by it in 1951}

In 1951 black rust occurred almost everywhere in Finland where spring wheat is grown. Table 1, which gives data concerning the occurrence of black rust based on the samples received by the Department of Plant Pathology, shows that the disease was found as far as Central Ostrobothnia $(\mathrm{Om})^{1}$, Kainuu $(\mathrm{Ok})$, and North Karelia (Kb). According to information received by the Department of Plant Pathology (3) and from other sources (5), in 1951 black rust was commonest and most injurious in the areas where spring wheat is chiefly grown: Varsinais-Suomi $(\mathrm{Ab})$, Satakunta (St), South Häme (Ta), as well as in parts of Uusimaa (N), South Ostrobothnia $(\mathrm{Oa})$, and North Häme $(\mathrm{Tb})$. Reports of great damage caused by black rust also arrived from Aland $(\mathrm{Al})$.

Accurate estimation of the damage caused by black rust in 1951 is difficult, for in many localities the low yields of that year must be attributed to exceptionally long droughts as well as to damage by black rust. According to the estimates carried out at the suggestion of the Agricultural Association of Varsinais-Suomi, the yield of spring wheat was only about half the normal yield in this district $\left.{ }^{2}\right)$. Reductions

1 Botanical provinces, see map on p. 50.

2 The area covered by this Association roughly corresponds with the botanical province of Varsinais-Suomi (Ab). 
Table 1. Analyses of spring wheat samples in 1951.

Samples were received from different parts of the country. Black rust on stalks: $0=$ no rust, $5=$ stalks totally covered by rust; the weight of 1000 kernels determined on unselected kernels taken from the heads; the length of the stalks includes roots; foot rot diseases: $0=$ no disease, $+=$ slightly infected, ++ heavily infected.

\begin{tabular}{|c|c|c|c|c|c|c|c|c|c|}
\hline $\begin{array}{l}\text { Botanical province } \\
\text { and commune (see } \\
\text { map on p. } 50 \text { ) }\end{array}$ & $\begin{array}{l}\text { Rust } \\
\text { on } \\
\text { stalks }\end{array}$ & $\begin{array}{l}\text { Weight } \\
\text { of } 1000 \\
\text { ker- } \\
\text { nerls }\end{array}$ & $\begin{array}{c}\text { Ave- } \\
\text { rage } \\
\text { height } \\
\text { of } \\
\text { stalks }\end{array}$ & $\begin{array}{l}\text { Foot } \\
\text { rot } \\
\text { dis- } \\
\text { ease }\end{array}$ & $\begin{array}{l}\text { Botanical province } \\
\text { and commune }\end{array}$ & $\begin{array}{c}\text { Rust } \\
\text { on } \\
\text { stalks }\end{array}$ & $\begin{array}{c}\text { Weight } \\
\text { of } 1000 \\
\text { ker- } \\
\text { nels }\end{array}$ & $\begin{array}{c}\text { Ave- } \\
\text { rage } \\
\text { height } \\
\text { of } \\
\text { stalks }\end{array}$ & $\begin{array}{l}\text { Foot } \\
\text { rot } \\
\text { dis- } \\
\text { ease }\end{array}$ \\
\hline$A l$ Aland & & & & & Ta South Häme & & & & \\
\hline Kumlinge & 2.7 & 26.5 & - & - & Ypäjä & 4.0 & 17.5 & 53 & + \\
\hline Kumlinge & 2.6 & 35.0 & 108 & - & Ypäjä & 3.6 & 14.6 & 104 & + \\
\hline Jomala & 2.5 & - & - & - & Somero & 3.1 & 11.0 & 67 & 0 \\
\hline Degerby & 2.0 & - & - & - & Jokioinen & 3.0 & 15.9 & 107 & + \\
\hline & & & & & Messukylä & 2.8 & 24.0 & 102 & + \\
\hline$A b$ Varsinais-Suomi & & & & & Kylmäkoski & 2.5 & 21.4 & 95 & + \\
\hline Aura & 4.0 & 14.5 & 95 & - & Koijärvi & 2.5 & 24.2 & - & - \\
\hline Parainen & 3.9 & 18.3 & 88 & 0 & Pälkäne & 2.2 & 31.4 & 86 & + \\
\hline Nauvo & 3.9 & 13.4 & 80 & 0 & Forssa & 1.7 & 14.8 & - & - \\
\hline Kemiö & 3.8 & 22.0 & - & - & Janakkala & 1.4 & 33.2 & 86 & + \\
\hline Karjala & 3.1 & 10.1 & - & - & Sa South Savo & & & & \\
\hline Parainen & 3.0 & 22.1 & - & + & Rautjärvi & 2.0 & 23.7 & - & - \\
\hline Nauvo & 2.8 & 34.8 & 103 & + & Ruokolahti & 1.3 & 36.4 & - & - \\
\hline Kemiö & 2.5 & 21.5 & 74 & + & Oa South Ostrobothr & ia & & & \\
\hline Korpoo & 2.4 & 16.0 & - & - & Alavus & 3.8 & 34.0 & - & - \\
\hline$N$ Uusimaa & & & & & Ilmajoki & 3.6 & 14.6 & 104 & - \\
\hline Anjala & 3.0 & 14.3 & - & - & Teuva & 2.4 & 15.1 & 102 & + \\
\hline Tammisaari & 2.9 & 28.2 & - & - & Töysä & 2.2 & 22.0 & 107 & ++ \\
\hline Perniö & 2.5 & 21.2 & - & - & Kuortane & 2.2 & 14.9 & 84 & + \\
\hline & & & & & Lehtimäki & 1.7 & 26.5 & 103 & ++ \\
\hline Ka South Karjala & & & & & Jalasjärvi & 1.7 & 31.7 & 104 & - \\
\hline Ylämaa & 1.0 & 17.8 & 113 & - & $\begin{array}{l}\text { Alavus } \\
\text { Lalasiärvi }\end{array}$ & 1.6 & 14.6 & 86 & 0 \\
\hline St Satakunta & & & & & Lapua & $\begin{array}{l}1.5 \\
0.8\end{array}$ & $\begin{array}{l}31.1 \\
23.8\end{array}$ & - & - \\
\hline Loimaa & 4.0 & 21.7 & 66 & + & Sb North Häme & & & & \\
\hline Köyliö & 4.0 & 18.9 & - & - & Virrat & 3.1 & 23.1 & 115 & + \\
\hline Suodenniemi & 3.8 & 26.7 & 85 & + & Pihlajavesi & 2.6 & 23.1 & - & - \\
\hline Suoniemi & 3.6 & 16.7 & 71 & + & Ähtäri & 2.2 & 25.0 & 103 & ++ \\
\hline Mouhijärvi & 3.1 & 24.0 & 113 & ++ & Pihlajavesi & 1.0 & 26.4 & - & - \\
\hline Alastaro & 3.1 & 25.6 & 61 & + & Ähtäri & 1.0 & 22.8 & 120 & + \\
\hline Suoniemi & 3.1 & 21.7 & 92 & 0 & Konnevesi & 0.4 & 23.1 & 112 & ++ \\
\hline Vampula & 3.0 & 21.0 & 74 & 0 & $S b$ North Savo & & & & \\
\hline Karkku & 2.9 & 18.6 & 92 & 0 & Savonranta & 2.3 & 27.9 & 108 & $\overline{-}$ \\
\hline Suodenniemi & 2.9 & 20.1 & 86 & + & $\begin{array}{l}\text { Savonranta } \\
\text { Tervo }\end{array}$ & 1.6 & -1.0 & 100 & - \\
\hline Parkano & 2.9 & 20.6 & 105 & 0 & Tuusniemi & 1.0 & - & - & - \\
\hline Yläne & 2.8 & 17.9 & - & - & $\begin{array}{l}\text { Tuusniemi } \\
K b \text { North Karjala }\end{array}$ & & & & - \\
\hline Ikaalinen & 2.6 & 21.6 & 114 & - & $K b$ North Karjala & & & & \\
\hline Suodenniemi & 2.5 & 29.1 & - & 一 & & 2.7 & 27.8 & 115 & 0 \\
\hline Kokemäki & 2.4 & 19.7 & - & - & Korpiselkä & 1.1 & 25.5 & 123 & + \\
\hline Hinnerjoki & 2.2 & 14.3 & 84 & - & Kiihtelysvaara & 0.5 & - & - & - \\
\hline $\begin{array}{l}\text { Viljakkala } \\
\text { Lappi T.1. }\end{array}$ & $\begin{array}{l}2.2 \\
1.9\end{array}$ & $\begin{array}{l}22.0 \\
26.3\end{array}$ & $\begin{array}{l}107 \\
112\end{array}$ & $\overline{+}$ & Om Central Ostrobo & nia & & & \\
\hline $\begin{array}{l}\text { Lappi T.1. } \\
\text { Ulvila }\end{array}$ & 1.8 & 18.9 & 112 & ++ & Soini & 3.3 & 26.8 & - & - \\
\hline Kokemäki & 1.6 & 39.6 & 94 & 0 & Evijärvi & 2.0 & - & - & - \\
\hline Karkku & 1.3 & 36.5 & 95 & + & $O k$ Kainuu & & & & \\
\hline Pori & 0.9 & 32.2 & 101 & 0 & Kuhmo & 0.5 & 40.8 & - & 一 \\
\hline
\end{tabular}


in yield, which in this case were due to both drought and black rust, are sure to have been equally heavy in other areas where spring wheat is usually grown, at least in Satakunta. The analyses of samples of spring wheat carried out at the Department of Plant Pathology throw further light on the causes which resulted in poor yields of spring wheat in 1951. The results of the analyses in Table 1 show that the low weights of 1000 kernels must be attributed to black rust and drought, and in some cases also to foot rot diseases. Damage by drought can be concluded from the height of the stalks. In cases where the height of the stalks was very low, damage was caused by drought, but the same samples could also show plenty of black rust. Thus it is impossible to state to what extent the poor yield was due to black rust and how far it was caused by drought. In cases where very little black rust was found and the height of the stalks was normal, the low weight of 1000 kernels must have been due to foot rot diseases caused by fungi (Cercosporella herpotrichoides FRON) or pests (Amblymerus graminum HARDH) which every year damage spring wheat in Finland, especially in the provinces of Satakunta, South Ostrobothnia and Central Ostrobothnia.

In view of these facts, only rough estimates of the damage caused by black rust in Finland in 1951 can be given. In the provinces where black rust was commonly found, the reduction in the yield caused by it was approximately $25-40 \%$.

The varieties of spring wheat commonly grown in Finland as well as in the other Northern countries are susceptible to black rust. This was shown, for instance, by the observations on varieties of spring wheat made in the experiments of the Departments of Plant Pathology and Plant Breeding of the Agricultural Research Centre in 1951. Excepting in spring wheat, black rust was very rare in cereals in 1951. In this connection it may be mentioned that black rust did not cause noteworthy damage in 1952 .

\section{Spreading of Berberidaceae in Finland}

According to the present view the barberry is necessary for the spread of the black rust in the climate of Northern Europe (cf. 2). Recently Johnson and GreEn (4) have indicated that rye black rust (Puccinia graminis secalis ERIKs. \& HeNn.) can overwinter in the uredial stage in Canada. However it has not been established that the uredospores of wheat black rust (P. graminis tritici ERIKs. \& HENN.) can survive the winter in Canada and the Northern United States.

In Finland it has been found that black rust often causes damage in the neighbourhood of barberry bushes. Information about this is often received at the Department of Plant Pathology. In the commune of Kymi in 1947, for instance, the yield of spring wheat near a barberry hedge was so low, due to heavy black rust, that the weight of 1000 kernels near the hedge was only $5 \mathrm{~g}$. Even at a distance of $2 \mathrm{~km}$. from the hedge the weight of 1000 kernels was somewhat lower than normal (7).

In 1952 the Department of Plant Pathology of the Agricultural Research Centre circulated an inquiry asking for information about Berberis and Mahonia bushes. The inquiry was addressed to nurseries, gardeners of towns and market towns, edu- 


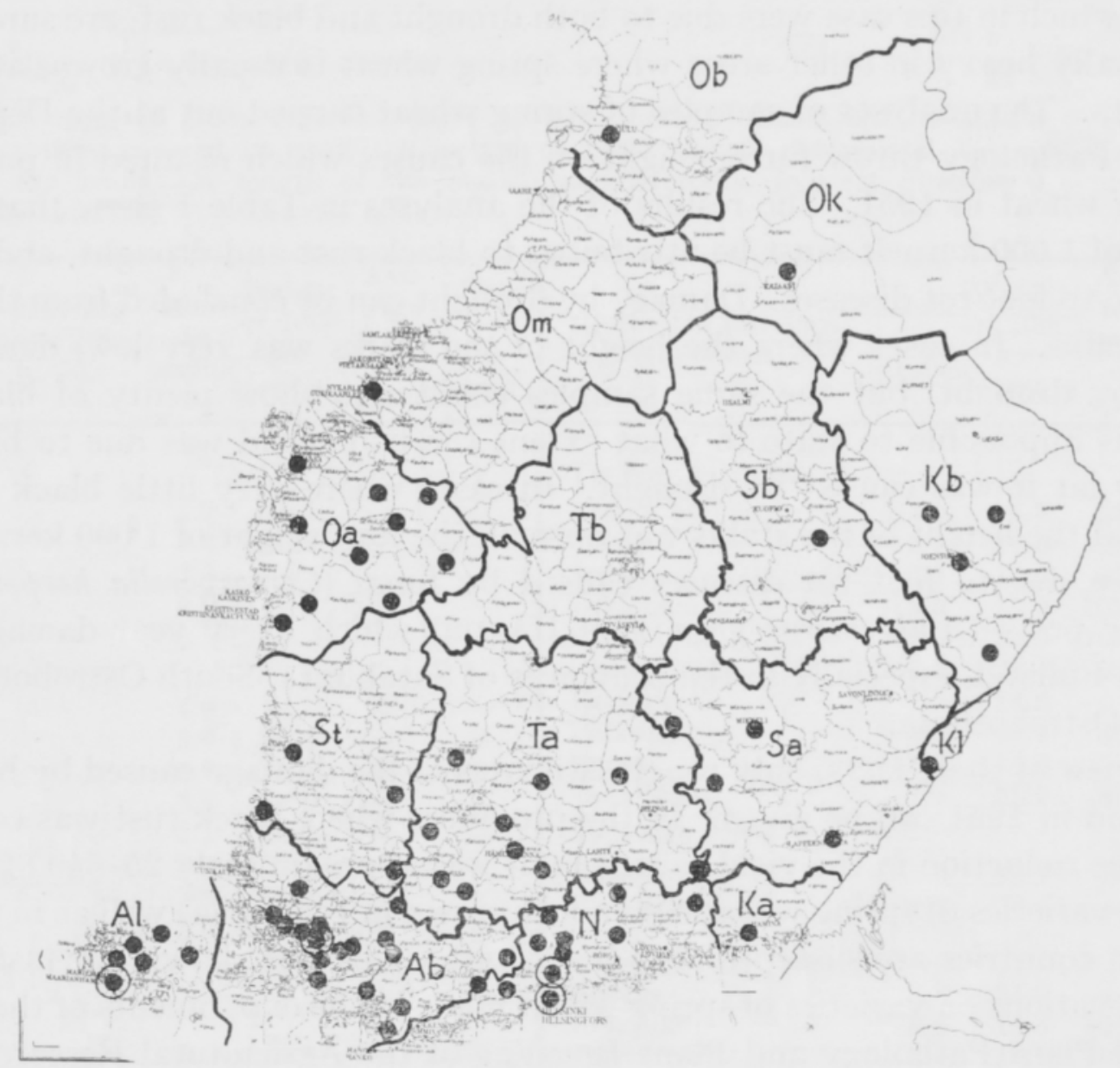

Occurrence of common barberry (Berberis vulgaris and B. vulgaris atropurpurea) in Finland according to information received at the Department of Plant Pathology, Agricultural Research Centre. Black spots indicate localities where the bush is found or at least was found until 1952. Spots with circles around them indicate localities about which frequent reports of the bush have been received.

Botanical provinces are indicated on the map by letters: $\mathrm{Al}=\mathrm{Aland} ; \mathrm{Ab}=$ Varsinais-Suomi; $\mathrm{N}=$ Uusimaa; $\mathrm{Ka}=$ South Karelia; $\mathrm{St}=$ Satakunta; Ta = South Häme; Sa = South Savo; Oa = South Ostrobothnia; $\mathrm{Tb}=$ North Häme; $\mathrm{Sb}=$ North Savo; Kb = North Karelia; Om = Central Ostrobothnia; $\mathrm{Oa}=$ North Ostrobothnia; Ok = Kainuu.

cational organizations, and to certain other persons interested in the question in different parts of the country. About 250 answers were received. The included mapshows the localities which sent information about the common barberry (Berberis vulgaris $\mathrm{L}$. and $B$. vulgaris atropurpurea $\mathrm{KocH})$. The results confirm the prevailing opinion that the common barberry is not a particularly usual ornamental bush in Finland. For a long time the Department of Plant Pathology has continuously urged nurseries not to grow the common barberry. Owing to this, nurseries, with a few exceptions, have not sold the common barberry for many years. The common barberry has been replaced by the Japanese barberry (Berberis Thunbergii DC. and B. Thunbergii atropurpurea HoRT.). The answers to the inquiry also showed that because of the commonness of black rust in 1952, steps have been taken to eradicate the common barberry in many places. 
Though the common barberry is not commonly grown in Finland, it is found in many parts of the country, as the information received shows. Most information was received from the south-western and southern parts of the country where this bush is often found in the parks of towns, in cemeteries, and in the gardens of estates. But the common barberry is not unknown in the eastern, northern, and central parts of the country, either, as the map of its distribution on p. 50 shows. A close inquiry might reveal its existence in many more communes than the map shows. Usually barberry bushes grow singly or in small groups of a few bushes, but whole hedges are found, for instance, in Helsinki. The Berberis bush is not found uncultivated in Finland but it may return to a wild state, as has been found to occur in some districts in Aland. Aecidial pustules of black rust were found on the leaves of many samples of the common barberry. In one case (N. Elimäki, Nurseries of Mustila, C. G. Tigerstedt, June 18, 1951) aecidial pustules of P. graminis were found on Berberis Sieboldii Mig.

In addition to Berberis spp. black rust can also infect Mahonia aquifolia (PURSH) Nutr. Foliage of this commonly grown ornamental plant is used in Finland in flower arrangements. The samples sent together with the answers to the inquiry showed aecidial pustules of black rust in six cases. Several samples with Puccinia mirabilissima PECK rust on Mahonia were also received.

Particulars about the occurrence of these kinds of rust on Mahonia, based on the samples received at the Department of Plant Pathology, are given below. All samples contained Puccinia mirabilissima and six samples P. graminis, which is specially mentioned at each occurrence.

$A b$. Piikkiö, Garden Department, leg. E. A. Jamalainen (E.A.J), Sept. 3, 1952. - Naantali, Kultaranta, Paavo Korventausta, Jun. 20, 1952. - Pohja, Brödtorp, Jun. 16, 1952. - Turku, City plantations, Aarne Hellemaa, Jul. 11, 1952. - Vihti, Ojakkala, K. Koivu, Jun. 26, 1952.

N. Elimäki, Nurseries of Mustila, C. G. Tigerstedt, Jun. 18, 1952, (sample of P. graminis at the same place). - Hyvinkää, Erkylä, E. Fabritius, Aug. 3, 1952. - Järvenpää, Training college for domestic science, Maija-Liisa Ahtela, Jun. 27, 1952 (sample of P. graminis). - Kauniainen, Helsinki, Paul Ohlsson, Jul. 4, 1952.

Ta. Forssa, Garden of Finlayson-Forssa Ltd., Eino Eramo, Jun. 25, 1952. - Hämeenlinna, Erkki Saarinen, Jun. 26, 1952. - Kuusankoski, garden of Kymi Ltd., K. Tiirakari, Jun. 19, 1952. - Tampere, Epilä, Kaarila, Pentti Mäkinen, Jun. 28, 1952 (sample of P. graminis). — Tervakoski, W. Pulkkinen, Aug. 24, 1948 (P.graminis at the same place). - Vanaja, Nurseries of Harviala, E. A. J., Oct. 9, 1951; E. A. J., Aug. 11, 1952 (P.graminis at the same place).

St. Karkku, Impi Rantanen, Aug. 18, 1945. - Kiukainen, Vaanii, Jun. 18, 1952. — Pori, City garden, Kosti Laaksonen, Jun. 28, 1952 (sample of $P$. graminis).

Ka. Myllykoski, gardens of Myllykoski paper-mill, Jun. 16, 1952. — Vehkalahti, Reitkalli, Gardening School, Toini Lindgren, Jul, 2, 1952.

Sa. Joutsa, Joutsa Gardens, Lauri Mäkelä, Jun. 25, 1952.

Om. Kokkola, City gardens, Jul. 11, 1952.

\section{Legal measures for the eradication of barberry bushes}

In many countries, for instance in Sweden and Denmark, legal measures have been taken to insure the eradication of species of Berberis susceptible to black rust. 
As the damage by black rust has not generally been very considerable in Finland, and as it was hoped that growers would cease cultivating the common barberry of their own free will, legal measures for the eradication of the bush have not been considered negessary before. The heavy outbreak of black rust in the summer of 1951, however, resulted in more vigorous measures with regard to the barberry bush. Thus the Department of Plant Pathology has drawn up a bill for the eradication of barberry bushes spreading black rust. The statute will be based on the Plant Protection Act of 1925, and is now being dealt with at the proper offices. The bill provides for the eradication of species of barberry susceptible to black rust. As yet the provision does not apply to Mahonia, because the disease seldom seems to be found on this species. Neither have Denmark and Sweden ordered Mahonia to be eradicated.

The eradication of the barberry bush from Finland may not guarantee that in years especially favourable to its spread, such as 1951, the black rust will not occur as an epidemic disease. During the summer of 1951, long rainless periods occurred when the spores of black rust could be borne long distances by wind. According to the literature, black rust spores can be carried even hundreds of kilometers in this way. It is possible that in 1951 the wheat black rust was carried to Finland from Southern Scandinavia, where the barberry is known to be very common, and where black rust did great damage. To what extent the black rust epidemic of 1951 was due to barberry bushes growing in Finland has not been proved.

Since the common barberry, as was reported above, can always be injurious to corn-fields in its neighbourhood at least, and as this bush is still found in many parts of Finland, its eracidation through legal decree is a necessary action.

\section{REFERENCES}

(1) Buchwald N. Fabritius \& Stapel, Chr. 1951. Sort rust og Berberis. (Danish). Ugeskrift for Landmaend, Nr. 39, p. 599-601. Kopenhagen.

(2) Gassner, G. \& Pieschel, E. 1934. Untersuchungen zur Frage der Uredoüberwinterung der Getreideroste in Deutschland. Phytopath. Zeitschrift, 7, p. $355-392$.

(3) Jamalainen, E. A. 1953. Viljan mustaruoste ja happomarjapensas sen levittäjänä. (Finnish). Maatalous ja Koetoiminta, VII, p. 83-92. Helsinki.

(4) Johnson, T. \& Green, G. J. 1952. Overwintering of Uredospores of Rye Stem Rust in Manitoba. Phytopathology, 42, p. 403-404.

(5) Pesola, Vilho ja Kivi, Erkki J. 1952. Tutkimus mustaruosteen tuhoista v. 1951 Lounais-Suomessa, erikoisesti lajikkeiden ja vahinkojen määrää silmälläpitäen. (Finnish). Maatalous, 45, p. 7-11. Helsinki.

(6) Stapel, Chr. 1952. Paa ny til Kamp mot de farlige Berberisbuske. (Danish). Ugerskrift for Landmaend, Nr. 21.

(7) YlimäKi, AARre 1947. Happomarjapensas mustaruosteen levittäjänä maassamme. (Finnish). Koetoiminta ja Käytäntö, No. 12, p. 5 - 8 . Helsinki.

(8) Åkerman, Å, Mac Key, James, Holmgren, Oskar, Wálstedt, Ivar, Waller, Eric \& Torpe, N. V. 1952. Vid Sveriges Utsädesförening samlade erfarenheter från 1951 års svartrostangrepp å vete. (Swedish). Sv. Utsädesförenings tidskrift, 62, p. 75-151. 
S E L O S T U :

MUSTARUOSTE JA BERBERIDACEAE-KASVIEN ESIINTYMINEN SUOMESSA

E. A. Jamalainen

Maatalouskoelaitoksen kasvitautiosasto, Tikkurila

Kirjoituksessa tehdään selkoa mustaruosteen (Puccinia graminis PERS.) levinneisyydestä ja vahingoista v. 1951 sekä Berberidaceae-kasvien esiintymisestä maassamme Maatalouskoelaitoksen kasvitautiosastolle kerääntyneiden tietojen mukaan (3). 